\title{
Phenology and Depth of Cold Acclimation in the Three Subspecies of Alnus maritima
}

\author{
James A. Schrader ${ }^{1}$ and William R. Graves \\ Department of Horticulture, Iowa State University, Ames, IA 50011-1100
} ADDITIONAL INDEX WORDS. seaside alder, subspp. oklahomensis and georgiensis, cold hardiness, tissue discoloration, woody
landscape plants, stress tolerance, plant biogeography

\begin{abstract}
Alnus maritima (Marsh.) Muhl. ex Nutt. is a large shrub or small tree with potential for use in managed landscapes. Because the three subspecies of A. maritima are indigenous only to areas with mild winter temperatures (USDA hardiness zones $7 \mathrm{a}$ and $7 \mathrm{~b}$ ), knowledge of their cold acclimation and cold hardiness is vital if they are to be used where winters are more harsh. Phenology and depth of cold hardiness were assessed by collecting stem samples seven times from 25 Sept. 2000 to 23 Apr. 2001, subjecting the samples to cold temperature ramping, and determining the lowest survival temperature (LST) via the tissue discoloration method. Samples were collected from indigenous plants of the three subspecies and from plants growing in a common garden near Ames, Iowa (USDA zone 5a). Results indicated that some plants from all three subspecies can survive midwinter extremes as low as $-80^{\circ} \mathrm{C}$; that plants grown in Ames achieved a greater depth of cold hardiness for most of the winter and were more uniform in cold hardiness than plants growing in warmer native sites; and that the three subspecies did not differ in phenology or depth of cold acclimation. Results of field trials with plots of 150 plants each installed in three northern hardiness zones (USDA zones 5a, 4a, and 3a) supported these conclusions by showing survival of all 450 plants. We resolved differences among subspecies by rating the percentage of stem tissue survival for each plant in the field plots. Subspecies maritima, from the northernmost provenance (the Delmarva Peninsula), showed the least stem death across all three plots (3.9\% tissue death), followed by subsp. georgiensis from northwestern Georgia (10\% tissue death), and subsp. oklahomensis from southern Oklahoma (12.8\% tissue death). Our results suggest that low temperatures should not limit the use of $A$. maritima in areas as harsh as USDA zone 3a. Selections based on cold hardiness may allow the use of $A$. maritima in areas with even colder winters.
\end{abstract}

Alnus maritima (seaside alder) is a rare woody species that occurs naturally as three subspecies from widely disjunct provenances in the United States. Alnus maritima subsp. oklahomensis Schrader \& Graves is found naturally in only two counties in south-central Oklahoma, A. maritima subsp. georgiensis Schrader \& Graves is isolated to one county in northwestern Georgia, and A. maritima subsp. maritima is found only on the Delmarva Peninsula in four counties in Maryland and two counties in Delaware (Schrader and Graves, 2002). There is a growing interest in the use of A. maritima in managed landscapes, but the proper geographical range for the use of this species has not been established. The natural distribution of $A$. maritima is limited to areas with relatively mild winter temperatures. Subspecies oklahomensis and maritima occur in USDA hardiness zone $7 \mathrm{a}$, where the mean minimum temperature is -15 to $-18{ }^{\circ} \mathrm{C}$, and subsp. georgiensis occurs in zone $7 \mathrm{~b}$ with a mean minimum of -12 to $-15^{\circ} \mathrm{C}$ (Agriculture Research Service, 1990). Although it appears that a lack of cold hardiness has limited A. maritima from areas with harsher winters, the present distribution of the species may be only a remnant of a much larger range that included areas as far north as Washington and Idaho (Furlow, 1979; Schrader and Graves, 2000). While Alnus is among the most cold hardy genera in the world (Vezina et al., 1997), little information is available on $A$. maritima. Therefore, our overall goal was to model the phenology and cold acclimation of this species.

The peculiar natural distribution of A. maritima provided a unique situation for the study of plant cold hardiness. Their isolation and extreme geographic disjunction suggest that the three subspecies of A. maritima may differ in phenology and depth of cold acclimation, therefore it is possible that genotypes from one of the subspecies may be more suitable for use in colder areas. We examined the cold hardiness of plants from all three subspecies growing both in natural

Received for publication 5 Sept. 2002. Accepted for publication 16 Jan. 2003. We thank Stanley Rice for assistance with tissue collection. We are grateful to Cynthia Haynes and Jeffery Iles for their helpful critiques of the manuscript.

${ }^{1}$ Corresponding author; e-mail jschrade@iastate.edu. environments and in field plots we established in Iowa and Minnesota. Our objectives were to characterize the phenology of winter dormancy, cold acclimation, and return of active shoot growth; to determine the effects of colder climates on the cold hardiness of $A$. maritima; to compare the cold hardiness of A. maritima with that of four other species of Alnus; and to establish the safe geographical range for A. maritima in managed landscapes as defined by plant cold hardiness. Our results will be used to develop guidelines for proper use of A. maritima in managed landscapes and will help guide plant breeding and selection efforts. They also provide new clues concerning the origin of the disjunct distribution of A. maritima.

\section{Materials and Methods}

\section{Cold acclimation and cold hardiness}

LABORATORY ASSESSMENTS. Two laboratory assessments of stem tissue hardiness were conducted. The first assessment was performed during Fall, Winter, and Spring 2000-01 by using the tissue discoloration method (Howell and Weiser, 1970), which can be more accurate than use of specific conductivity, tetrazolium staining, and multiple freezing point exotherms (Stergios and Howell, 1973). Tissue discoloration also has proven consistently accurate with numerous woody-plant taxa (Lindstrom and Del Hierro, 1992; Lindstrom and Dirr, 1991; McNamara and Pellet, 1996; Pellet et al., 1981). We examined the cold acclimation and cold hardiness of plants of the three subspecies of A. maritima and compared the acclimation and hardiness of plants growing in natural habitats (USDA hardiness zone 7) with those growing in a common garden near Ames, Iowa (USDA hardiness zone 5a).

Samples of stems formed in 2000 were collected on 25 Sept., 30 Oct., and 4 Dec. 2000, and 8 Jan., 12 Feb., 18 Mar., and 22 Apr. 2001 from plants of all three subspecies in situ (growing in Oklahoma, Georgia, and on the Delmarva Peninsula) and ex situ (growing together in a randomized plot in Ames). Five mature trees of each subspecies were sampled in situ, along with five 3-year-old, halfsibling groups of each subspecies ex situ. Each half-sibling group 
consisted of six plants propagated from the seed of one parent tree in its native provenance. Therefore, the experimental design was a $3 \times 2$ factorial (Cochran and Cox, 1992) executed on seven different dates and consisting of three treatments for subspecies (subspp. oklahomensis, georgiensis, and maritima) crossed with two treatments of habitat (native/in situ and Iowa/ex situ).

Stem samples from all collection sites were transported on ice to Iowa State Univ. within $24 \mathrm{~h}$. Each stem section was trimmed to $5 \mathrm{~cm}$ in length after removing the terminal $5 \mathrm{~cm}$ of the shoot apex, was wrapped in moist paper toweling, and was placed in a 16-mmdiameter culture tube that was held at $4{ }^{\circ} \mathrm{C}$ in a programmable freezer (ScienTemp, Adrian, Mich.) until the start of temperature ramping $(\leq 12 \mathrm{~h})$. After all samples were prepared, the temperature was lowered and held at $-2{ }^{\circ} \mathrm{C}$ for $1 \mathrm{~h}$. Each sample then was nucleated with ice crystals, controls were removed and placed in a refrigerator at 4 ${ }^{\circ} \mathrm{C}$, and the temperature was lowered at $2^{\circ} \mathrm{C}$ per hour. Temperatures were monitored in culture tubes by using a datalogger and four thermocouple probes (CR23X; Campbell Scientific, Logan, Utah) positioned at disparate locations in the freezer. Four replicates from each plant source were removed at each $4{ }^{\circ} \mathrm{C}$ interval. Upon removal, samples were allowed to thaw slowly by placing them on ice for $1 \mathrm{~h}$ and then holding them at $4{ }^{\circ} \mathrm{C}$ for $12 \mathrm{~h}$. After thawing, culture tubes were covered with parafilm and incubated in a dark growth chamber at $22^{\circ} \mathrm{C}$ for $14 \mathrm{~d}$. After incubation, each stem sample was sectioned longitudinally and examined for tissue discoloration under a dissecting microscope (Fig. 1). Each stem section was rated as alive (cambium and phloem light green or clear) or dead ( $\geq 60 \%$ of cambium and phloem brown). The lowest survival temperature (LST) (Fuchigami et al., 1971) was determined for each source plant as the minimum treatment temperature at which $\geq 75 \%$ (three out of four) of the replications survived.

We assessed response to seven temperatures (range of $24^{\circ} \mathrm{C}$ ) on each date. Ranges were -2 to $-22^{\circ} \mathrm{C}$ on 25 Sept., -6 to $-30{ }^{\circ} \mathrm{C}$ on 30 Oct., -34 to $-58^{\circ} \mathrm{C}$ on 4 Dec., -56 to $-80^{\circ} \mathrm{C}$ on 8 Jan., -38 to

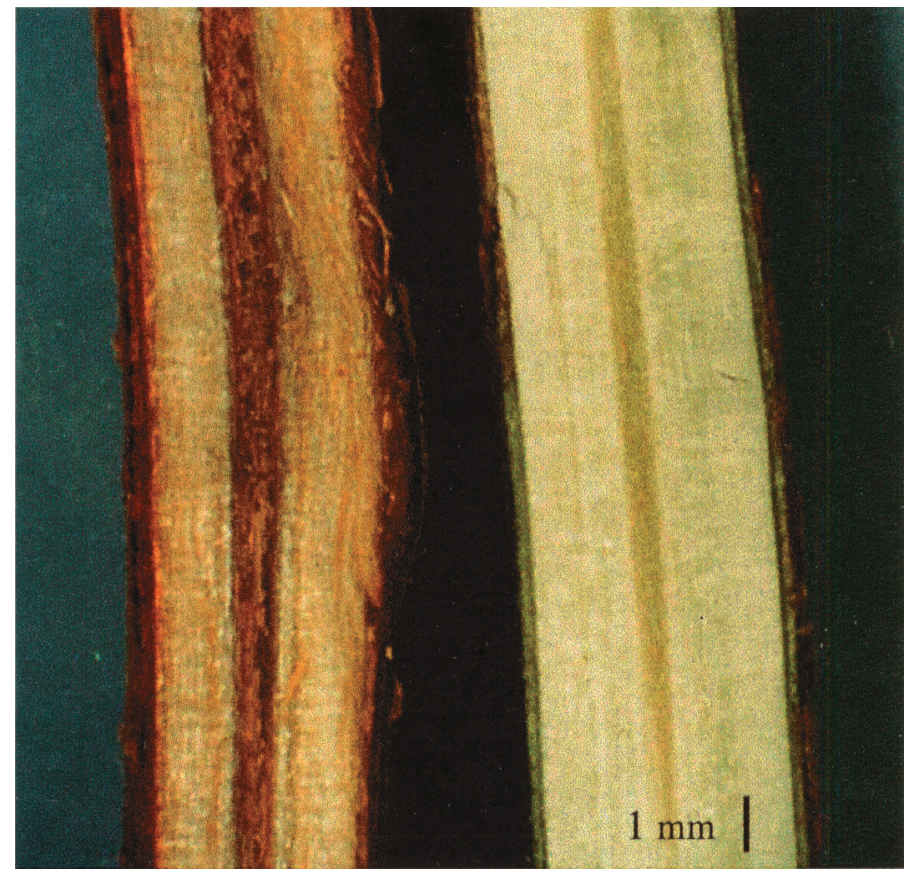

Fig. 1. Diagnostic characteristics for the tissue-discoloration method of coldhardiness analysis. After receiving chilling treatments followed by $14 \mathrm{~d}$ of incubation at $22^{\circ} \mathrm{C}$, stem samples of Alnus maritima were rated as dead when cambium and phloem tissues were dark brown and necrotic (left) or alive when cambium and phloem tissues appeared light green and healthy (right). This figure may be viewed in color at http://www.hort.iastate.edu/graves/. $-62^{\circ} \mathrm{C}$ on $12 \mathrm{Feb} .,-34$ to $-58^{\circ} \mathrm{C}$ on $18 \mathrm{Mar}$., and -30 to $-54^{\circ} \mathrm{C}$ on $22 \mathrm{Apr}$. There were samples on each date that were not killed by the lowest temperature applied. For analysis purposes, these samples were assigned an LST that coincided with the most severe treatment for that assessment date, even though the LST may have actually been lower. Analyses focused on cold acclimation (increase in cold hardiness) and deacclimation (loss of cold hardiness) of plants of the three subspecies through the fall, winter, and spring and on defining their peak cold hardiness in midwinter. The effects of collection date, in situ vs. ex situ habitat, and subspecies were determined by analysis of variance and Fisher's least significant difference test. Analysis of variance showed no interaction between the main effects of date, habitat, or subspecies, establishing that the main effects of these parameters were independent (Cochran and Cox, 1992). Because the main effects were independent we were able to analyze and report these effects separately. Replication was $n=10$ for subspecies, $n=$ 15 for habitat, and $n=30$ for collection date. Cold acclimation and hardiness results were also modeled with the current season's daily minimum temperatures and record daily minimum temperatures for locations in zones $5 \mathrm{a}, 4 \mathrm{a}$, and 3 a to predict the safe geographical range for the use of $A$. maritima in managed landscapes.

The second laboratory assessment examined the midwinter cold hardiness of A. maritima and its three subspecies in another way. Whole shoots were collected on 30 Jan. 2002 from 4-year-old trees of all subspecies at a research station of Iowa State Univ. near Ames. After wrapping the basal 5 to $10 \mathrm{~cm}$ of each shoot with moist paper towel surrounded by parafilm, the frozen, whole shoots were placed in the programmable freezer and held at $-6^{\circ} \mathrm{C}$ for $10 \mathrm{~h}$. The temperature then was lowered $3{ }^{\circ} \mathrm{C}$ per hour. One shoot from each subspecies was removed at each of five treatments $(-30,-40,-50$, -60 , and $-70^{\circ} \mathrm{C}$ ) and allowed to thaw slowly by placing it outdoors for $\geq 12 \mathrm{~h}$ at -2 to $-6^{\circ} \mathrm{C}$. For the sixth treatment at $-80^{\circ} \mathrm{C}$, samples were allowed to remain in the freezer as the programmed temperature slowly returned from -80 to $-6{ }^{\circ} \mathrm{C}$ over the $12-\mathrm{h}$ period. We

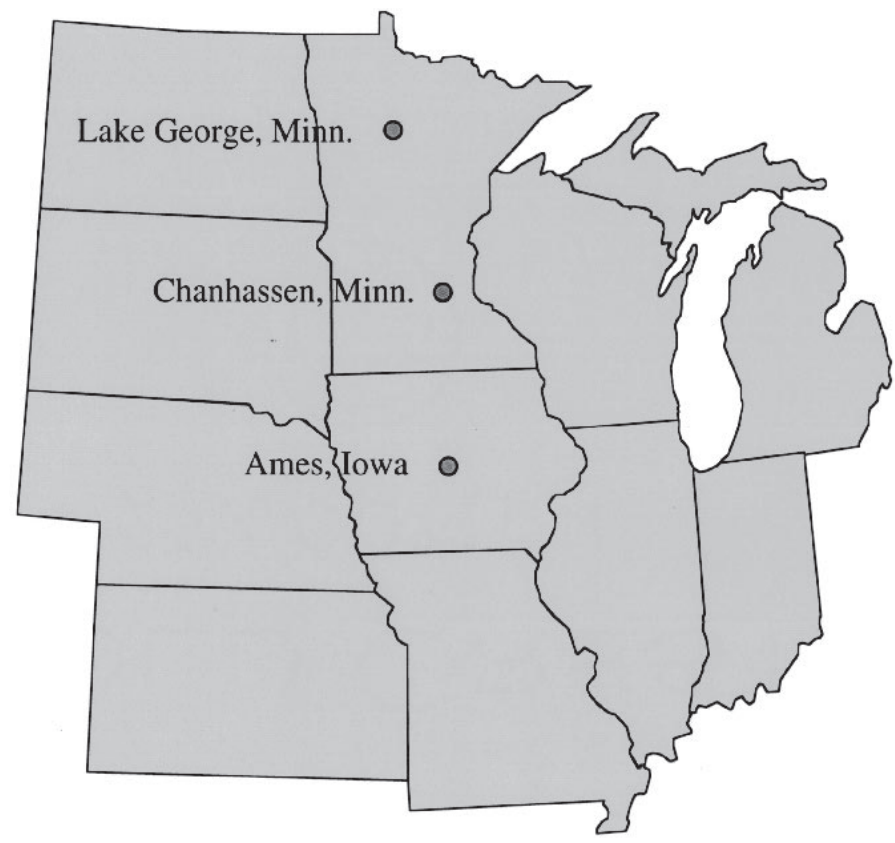

Fig. 2. Field trials to evaluate the winter hardiness of Alnus maritima and four other species of Alnus were established at three sites in the upper-midwestern United States: at a research station of Iowa State Univ. near Ames, Iowa (USDA hardiness zone 5a, mean annual minimum -26 to $-29{ }^{\circ} \mathrm{C}$ ); at the Minnesota Landscape Arboretum in Chanhassen, Minn. (USDA hardiness zone 4a, mean annual minimum -32 to $-34^{\circ} \mathrm{C}$ ); and on a site near Lake George, Minn. (USDA zone $3 \mathrm{a}$, mean annual minimum -37 to $-40^{\circ} \mathrm{C}$ ). 
believe this provided a stringent test of cold-hardiness for these samples by maintaining them at extremely cold temperatures for a long period $\left(\leq-60^{\circ} \mathrm{C}\right.$ for $\approx 10 \mathrm{~h}$ ) and by providing a realistic rate of temperature change during warming. After thawing, the basal end of each shoot was held in forcing solution of gibberellic acid (25 $\left.\mathrm{mg} \cdot \mathrm{L}^{-1}\right), 8$-hydroxyquinoline $\left(200 \mathrm{mg} \cdot \mathrm{L}^{-1}\right)$, and sucrose $\left(20 \mathrm{~g} \cdot \mathrm{L}^{-1}\right)$ in distilled-deionized $\mathrm{H}_{2} \mathrm{O}$. The shoots were held on a greenhouse bench at 20 to $22{ }^{\circ} \mathrm{C}$ under a 16-h photoperiod by using two 400 $\mathrm{W}$ high-pressure sodium lamps to supplement natural irradiance. Shoots were monitored each day for evidence of budbreak and new growth, as an estimate of the coldest temperature at which the trees could survive in midwinter.

Field TRIALs. In Spring 2000, 1-year-old seedlings of A. maritima, Alnus serrulata (Ait.) Willd., Alnus glutinosa (L.) Gaertn., Alnus nitida (Spach) Endl., and Alnus nepalensis D. Don were installed at three sites that differed in winter climate severity. These field plots were established at a research station of Iowa State Univ. near Ames (USDA hardiness zone 5a, mean annual minimum of -26 to $-29^{\circ} \mathrm{C}$ ); at the Minnesota Landscape Arboretum in Chanhassen (USDA hardiness zone $4 \mathrm{a}$, mean annual minimum of -32 to -34 ${ }^{\circ} \mathrm{C}$ ); and on a site near Lake George (USDA zone 3a, mean annual minimum of -37 to $-40{ }^{\circ} \mathrm{C}$ ) (Fig. 2). At all three locations, ten half-sibling groups of seedlings of each subspecies of A. maritima, three half-sibling groups of seedlings of $A$. serrulata (one group each from Delaware, Georgia, and Arkansas), and one half-sibling group each of $A$. glutinosa, $A$. nitida, and $A$. nepalensis were placed in a completely randomized design, with five replications per halfsib group. Therefore, the experimental design was a $5 \times 3$ factorial (Cochran and Cox, 1992) at the species level with five treatments of species (A. maritima, A. serrulata, A. glutinosa, A. nitida, and A. nepalensis) crossed with three treatments of plot location (Ames, Chanhassen, and Lake George) and a $6 \times 3$ factorial at the infraspecific level with six treatments for subspecies/population (A.maritima subspp. oklahomensis, georgiensis, and maritima and A. serrulata populations in Delaware, Georgia, and Arkansas) crossed with three treatments of plot location (Ames, Chanhassen, Lake George). Alnus serrulata is a species with a continuous distribution that covers nearly the same range as the disjunct distribution of $A$. maritima. The population of $A$. serrulata from Georgia is sympatric with $A$. maritima subsp. georgiensis, the population of $A$. serrulata from Delaware is sympatric with subsp. maritima, and the population of A. serrulata in Arkansas is close to subsp. oklahomensis, but 150 $\mathrm{km}$ farther north.

Plots were irrigated twice each month from 1 May to 1 Oct. during the two growth seasons to ensure that drought did not affect growth and survival. Plants were measured at the end of the first season (early October 2000) and again the following spring (mid-June 2001) to assess winter survival and growth in the three different climates. Measurements were plant survival (percentage of trees from each taxon that exhibited any new growth from any position on the existing shoot by mid-June 2001), tissue survival (percentage of the existing shoot system that broke bud and grew), and canopy volume in June 2001. The canopy volume was calculated by multiplying the shoot height by the horizontal canopy area (area of an ellipse calculated from the north-south and east-west canopy diameter measurements) (Schrader and Graves, 2002). The effects of genotype (species, subspecies, or population) and plot location were determined by analysis of variance and Fisher's least significant difference test. Analysis of variance showed no interaction between the main effects of genotype and plot location, establishing that the main effects of these parameters were independent (Cochran and Cox, 1992). Because the main effects were independent, we were able to analyze and report these effects separately, taking advantage of hidden replication. At the species level, replication was $\mathrm{n}=450$ for A. maritima; $\mathrm{n}=45$ for $A$. serrulata; and $\mathrm{n}=15$ for $A$. glutinosa, A. nitida, and $A$. nepalensis across all three plots. At the infraspecific level, replication was $\mathrm{n}=150$ for each subspecies of $A$. maritima and $\mathrm{n}=15$ for each population of $A$. serrulata across the three plots. Replication was $\mathrm{n}=50$ for the subspecies of $A$. maritima within each plot and $\mathrm{n}=150$ for the species $A$. maritima at each plot.

\section{Phenology of dormancy and active growth}

The phenology of budbreak, shoot growth, and leaf abscission was characterized for 2-year-old A. maritima growing at a research station of Iowa State Univ. near Ames during 2001. Data were collected from 125 plants each from subspp. maritima and georgiensis (25 half-sibling groups each) and 105 plants from subsp. oklahomensis (21 half-sibling groups) that were installed in June 2000 in a completely randomized plot. Plants were measured each day during the time of budbreak, once a month (24 May, 24 June, 25 July, 24 Aug., 24 Sept., and 5 Oct.) during the time of active growth, and once every $3 \mathrm{~d}$ during the time of leaf abscission. Percentage budbreak was the percentage of plants that had broken bud on or before each assessment date. A plant was considered to have broken bud when three or more of its buds had opened sufficiently that the adaxial side of a leaf could be seen. Shoot growth was a rate calculated as the increase in canopy volume divided by the number of days of growth and measured in cubic centimeters per day. Leaf abscission was measured as the percentage (estimated to the nearest $10 \%$ ) of total seasonal leaves remaining on a plant on each assessment date.

Daily minimum temperatures for the Ames plot were recorded by using a CR23X datalogger (Campbell Scientific, Logan, Utah). Daily minimum temperatures for the sites in Minnesota were obtained from the Historical Data Retrieval and Climate Summaries web page (http://climate.umn.edu/doc/historical.htm). All data for 100-year record daily minima and 100-year mean daily minima were obtained from the Climatology Index Page (The Weather Channel, 1995-2002). Data for the 50-year record daily minima for Ames were obtained from the Climatological Data Selection Page (http: //mesonet.agron.iastate.edu/climodat/table.html). To help determine in which part of the winter season seedlings may have been damaged and to establish where A. maritima can safely be used in the landscape, we plotted the phenology of cold hardiness of A. maritima (LSTs for the plants in Ames) recorded in the first lab assessment with the daily minimum temperatures for winter $2000-01$ and the 50 - or 100 -year record minima for the three cold hardiness sites. Data were analyzed by using the general linear models (GLM) procedure and the least significant difference (LSD) option of SAS/STATsoftware, Version 6.12 (1989-96).

\section{Results}

\section{Cold acclimation and cold hardiness}

LABORATORY ASSESSMENTS. Results from the first laboratory assessment showed ample cold hardiness for all three subspecies on all seven dates throughout the winter of 2000-01 when compared with the 100-year record daily minima from regions where they are found naturally (Table 1). Although the winter climates where the three subspecies are indigenous vary, as shown by the mean and record minimum temperatures for these regions (Table 1), the LSTs were not different among the three subspecies on any of the seven dates assessed. On four of the assessment dates, cold hardiness was greater (lower LST) for plants in Ames than for plants in their native habitats. Cold acclimation (shown by the decreasing LSTs for 25 Sept., 30 Oct., 4 Dec., and 8 Jan.) and midwinter peak cold 
Table 1. Lowest survival temperature (LST) in ${ }^{\circ} \mathrm{C}$ for Alnus maritima subspp. oklahomensis, georgiensis, and maritima assessed on seven dates during winter 2000-01. Samples were collected on the same dates both from trees growing in native habitats and from trees of the three subspecies growing in a common garden near Ames, Iowa. Mean LST for A. maritima in each habitat and the mean LST for A. maritima across habitats are included along with the number of samples out of 30 that exceeded the test range on each assessment date. Also included are the 100 -year record daily minimum temperature $\left({ }^{\circ} \mathrm{C}\right)$ and the 100 -year mean daily minimum temperature $\left({ }^{\circ} \mathrm{C}\right)$ for the seven dates, recorded for Ames, Iowa, and the areas where the three subspecies are nativez.

Category

and Date $2000-01$

\begin{tabular}{|c|c|c|c|c|c|c|c|}
\hline source & 25 Sept. & 30 Oct. & 4 Dec. & 8 Jan. & 12 Feb. & 19 Mar. & 23 Apr. \\
\hline \multicolumn{8}{|l|}{ Subspecies LSTy } \\
\hline oklahomensis & $-13 \mathrm{a}$ & $-26 \mathrm{a}$ & $-50 \mathrm{a}$ & $-61 \mathrm{a}$ & $-55 \mathrm{a}$ & $-48 \mathrm{a}$ & $-36 \mathrm{a}$ \\
\hline georgiensis & $-16 \mathrm{a}$ & $-25 \mathrm{a}$ & $-52 \mathrm{a}$ & $-66 \mathrm{a}$ & $-57 \mathrm{a}$ & $-45 \mathrm{a}$ & $-40 \mathrm{a}$ \\
\hline maritima & $-12 \mathrm{a}$ & $-25 \mathrm{a}$ & $-53 \mathrm{a}$ & $-62 \mathrm{a}$ & $-56 \mathrm{a}$ & $-50 \mathrm{a}$ & $-41 \mathrm{a}$ \\
\hline \multicolumn{8}{|l|}{ Record daily minimum temperature ${ }^{x}$} \\
\hline Tishomingo, Okla. & $7(14)$ & $-10(7)$ & $-7(1)$ & $-18(-3)$ & $-17(-1)$ & $-11(6)$ & $3(12)$ \\
\hline Cartersville, Ga. & $4(13)$ & $-4(6)$ & $-9(2)$ & $-13(-1)$ & $-14(0)$ & $-6(5)$ & $-2(9)$ \\
\hline Seaford, Del. & $1(11)$ & $-6(4)$ & $-12(-1)$ & $-12(-4)$ & $-19(-4)$ & $-11(1)$ & $-1(6)$ \\
\hline Ames, Iowa & $2(9)$ & $-7(1)$ & $-20(-7)$ & $-27(-13)$ & $-28(-11)$ & $-16(-2)$ & $-3(5)$ \\
\hline \multicolumn{8}{|l|}{ Habitat meansw } \\
\hline Native habitat & $-12.7 \mathrm{a}$ & $-23.9 \mathrm{a}$ & $-49.2 \mathrm{a}$ & $-64.1 \mathrm{a}$ & $-50.3 \mathrm{a}$ & $-40.9 \mathrm{a}$ & $-30.0 \mathrm{a}$ \\
\hline Ames, Iowa & $-14.8 \mathrm{a}$ & $-27.1 \mathrm{~b}$ & $-53.5 \mathrm{a}$ & $-61.9 \mathrm{a}$ & $-61.7 b$ & $-54.5 \mathrm{~b}$ & $-48.1 b$ \\
\hline A. maritima ${ }^{\mathrm{v}}$ & $-13.7 \mathrm{a}$ & $-25.5 b$ & $-51.3 \mathrm{~d}$ & $-63.0 \mathrm{f}$ & $-56.0 \mathrm{e}$ & $-47.7 \mathrm{~d}$ & $-39.1 \mathrm{c}$ \\
\hline Number of samples exceeding test range ${ }^{u}$ & $2 @-22$ & $6 @-30$ & $16 @-58$ & $7 @-80$ & $18 @-62$ & $8 @-58$ & $5 @-54$ \\
\hline
\end{tabular}

${ }^{2}$ Subsp. oklahomensis is found near Tishomingo, Okla.; subsp. georgiensis is found near Cartersville, Ga.; and subsp. maritima is found near Seaford, Del.

${ }^{y}$ Subspecies means across habitats (main effects of subspecies, $n=10$ ). Subspecies means within each column followed by the same letter are not significantly different at $P \leq 0.05$ according to Fisher's least significant difference test.

xNumbers outside parentheses are the 100-year record daily minimum temperatures; numbers inside parentheses are the 100-year mean daily minimum temperatures.

wMean LST for the species A. maritima in situ and ex situ (main effects of habitat, $\mathrm{n}=15$ ). Habitat means within each column followed by the same letter are not significantly different at $P \leq 0.05$ according to Fisher's least significant difference test.

${ }^{v}$ Mean LST for the species A. maritima across subspecies and habitats (main effects of collection date, $\mathrm{n}=30$ ). Species means followed by the same letter are not significantly different at $P \leq 0.05$ according to Fisher's least significant difference test.

"Number of samples out of 30 that exceeded the temperature range for the test date, followed by the minimum temperature $\left({ }^{\circ} \mathrm{C}\right)$ tested on that date.

hardiness (LSTs for 8 Jan.) were similar for plants growing in the two habitats, but plants in native habitats deacclimated (lost cold hardiness) more quickly than did plants growing in Ames (Table 1). Even though plants deacclimated sooner in native sites, their LSTs were more than sufficient for plants to withstand the record minima in their natural environments. The mean LST for all 30 samples on 8 Jan. indicates that, as a species, A. maritima can withstand midwinter extremes as low as $-63{ }^{\circ} \mathrm{C}$. Because seven samples exceeded the lower limit of the test range on $8 \mathrm{Jan} .\left(-80^{\circ} \mathrm{C}\right)$, A. maritima may be cold hardy at even lower temperatures, and at least some of the genotypes were cold hardy at $-80^{\circ} \mathrm{C}$ or lower.

The strong midwinter cold hardiness of A.maritima was confirmed by our second laboratory assessment. Budbreak was observed on all samples from all three subspecies and all six treatments $(-30,-40$, $-50,-60,-70$, and $-80^{\circ} \mathrm{C}$ ) by $20 \mathrm{Feb} .2002$, within three weeks of cold-temperature ramping. New foliage was produced by all samples until the termination of the experiment on 13 Mar. 2002. New growth took place from both apical and axillary buds, with no visible signs of damage from cold stress on any of the shoots (Fig. 3 ).

Field trials. Two-year-old trees of A. maritima, A. serrulata, and A. glutinosa showed $100 \%$ plant survival at all three of the cold-hardiness plots during their first winter (2000-01), while the other two species, A. nitida and A. nepalensis, showed $0 \%$ survival (Table 2). Of the three species that survived, A. maritima showed the greatest tissue survival per plant, $91.1 \%$ when averaged across all three cold-hardiness plots. At the infraspecific level, we compared plant and tissue survival of the three subspecies of A. maritima with genotypes from three populations of $A$. serrulata. All plants from both species survived the colder winters in Iowa and Minnesota, but there was a difference in tissue survival among the six populations. Alnus maritima subsp. maritima showed the greatest percentage of tissue survival $(96.1 \%)$, and the three subspecies of $A$. maritima each showed greater tissue survival than A. serrulata from their native areas (Table 2).

Although there were no differences in plant survival among the three subspecies or the three cold-hardiness plots, there were differences in tissue survival and canopy development at these levels (Table 3). At the plot near Ames (USDA zone 5a), winter damage was negligible for all three subspecies, but subspp. oklahomensis and georgiensis had greater growth (greater canopy volume) than subsp. maritima in this environment. At Chanhassen (USDA zone 4a), subsp. maritima showed greater tissue survival than subsp. georgiensis, but overall growth was not different for these two subspecies, and growth of subsp. oklahomensis was greater than that of subsp. maritima. At the plot near Lake George (USDA zone 3a), subsp. maritima again showed the greatest percentage of tissue survival $(91.5 \%)$, but tissue damage and slow growth limited the size of plants from all three subspecies (Table 3). Means for subspecies across the three plots confirmed that subsp. maritima was the most cold hardy (96.1\% tissue survival) of the three subspecies in climates of the Upper Midwest in 2000-01, but they also show that subsp. maritima grew more slowly than subsp. oklahomensis. Combining the results for the three subspecies, means for the three cold-hardiness plots show that tissue damage increased for A. maritima along with the severity of the winter environments at the three locations (Table 3). Yet, even in the severe environment of Lake George (USDA zone 3a), the 2-year-old seedlings showed $80.4 \%$ tissue survival overall. 

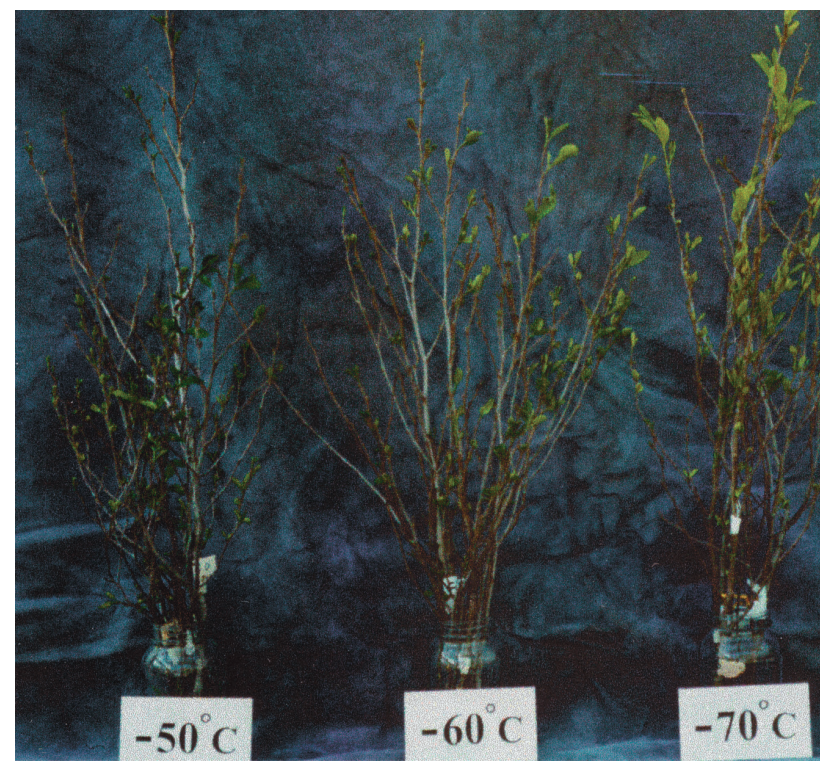

Fig. 3. Growth of shoots from the three subspecies of Alnus maritima after they had received laboratory chilling treatments as low as $-80^{\circ} \mathrm{C}$. Shoots from all three subspecies are shown together because budbreak and growth were observed on all samples from all three subspecies under all treatment temperatures. Shoots were collected on 30 Jan. 2002 from 4-year-old trees near Ames, Iowa. This figure may be viewed in color at http://www.hort.iastate.edu/graves/.

The cold hardiness of A. maritima, projected from 2000-01 data, exceeded the daily minimum temperatures at all three sites for the entire winter of 2000-01 (Fig. 4) and the record minimum temperatures except for an extremely low temperature of $-25.6^{\circ} \mathrm{C}$ for Lake George recorded for 27 Oct. (Fig. 4).

Table 2. Plant and tissue survival for 2-year-old trees from five species of Alnus after winter 2000-01. Winter survival is compared separately at specific and infraspecific levels by using combined data from cold-hardiness plots in Ames, Iowa (USDA zone 5a); Chanhassen, Minn. (USDA zone 4a); and Lake George, Minn. (USDA zone 3a).

\begin{tabular}{lcc}
\hline Taxon & Plant survivalz (\%) & Tissue survivaly (\%) \\
\hline Species level & & \\
Alnus maritima & $100 \mathrm{a}^{\mathrm{w}}$ & $71.1 \mathrm{a}$ \\
Alnus serrulata & $100 \mathrm{a}$ & $78.1 \mathrm{~b}$ \\
Alnus glutinosa & $100 \mathrm{a}$ & $0 \mathrm{c}$ \\
Alnus nitida & $0 \mathrm{~b}$ & $0 \mathrm{c}$ \\
Alnus nepalensis & $0 \mathrm{~b}$ & \\
Infraspecific levelv & & $87.2 \mathrm{bc}$ \\
Alnus maritima & $100 \mathrm{a}$ & $90.0 \mathrm{~b}$ \\
subsp. oklahomensis & $100 \mathrm{a}$ & $96.1 \mathrm{a}$ \\
subsp. georgiensis & $100 \mathrm{a}$ & $79.8 \mathrm{~d}$ \\
subsp. maritima & $100 \mathrm{a}$ & $73.4 \mathrm{~d}$ \\
Alnus serrulata & $100 \mathrm{a}$ & $81.2 \mathrm{~cd}$ \\
Arkansas & $100 \mathrm{a}$ & \\
Georgia & & \\
Delaware & & \\
\hline
\end{tabular}

zPercentage of trees from each taxon that exhibited any new growth from any position on the existing shoot by mid-June, 2001.

yPercentage of the existing shoot that broke bud and grew.

${ }^{\mathrm{x}} \mathrm{n}=450$ for $A$. maritima; $\mathrm{n}=45$ for $A$. serrulata $; \mathrm{n}=15$ for $A$. glutinosa, A. nitida, and A. nepalensis.

${ }^{w}$ Means within columns and taxonomic levels followed by the same letter are not significantly different at $P \leq 0.05$ according to Fisher's least significant difference test.

${ }^{v} \mathrm{n}=150$ for each subspecies of A. maritima and $\mathrm{n}=15$ for each population of $A$. serrulata.
Phenology of dormancy and active growth

The growth phenology of $A$. maritima varied among the three subspecies when plants were assessed in a common garden environment in Ames in 2001 (Fig. 5). Subspecies maritima was the earliest to break bud, followed by subsp. oklahomensis and then subsp. georgiensis. The first plants of subsp. maritima showed budbreak on 11 Apr., and the last plants from subsp. georgiensis broke bud on 23 Apr. For the remainder of April and the beginning of May, growth rates were consistent with the order of budbreak, but by the second week in May, subsp. oklahomensis had the highest rate of growth. By the second week in June, subsp. georgiensis had the highest growth rate, and it continued to grow faster than the other two subspecies until early September (Fig. 5). The timing of growth during the season was similar for subspp. georgiensis and maritima. Both of these taxa showed a peak in growth rate by late July, while subsp. oklahomensis maintained $-80^{\circ} \mathrm{C}$ its highest rate of growth from mid-July to mid-August. Subspecies maritima had the lowest growth rate throughout the season. It was the first of the three subspecies to enter dormancy and the first to undergo leaf abscission. Subspecies oklahomensis was the last toenterdormancy and the last to shed its leaves (Fig. 5). All three of the subspecies had entered dormancy by 5 Oct.

Table 3. Tissue survival and canopy development of 2-year-old trees of the three subspecies of Alnus maritima assessed after winter 2000-01. Means for subspecies are compared separately for trees from cold-hardiness plots in USDA zones 5a (Ames, Iowa), 4a (Chanhassen, Minn.), and 3a (Lake George, Minn.), followed by the means for subspecies across the three plots and a comparison of plot means for the survival and growth of the species A. maritima.

\begin{tabular}{|c|c|c|}
\hline $\begin{array}{l}\text { Plot location } \\
\text { and } \\
\text { subspecies }^{z}\end{array}$ & $\begin{array}{c}\text { Tissue } \\
\text { survivaly }(\%)\end{array}$ & $\begin{array}{c}\text { Canopy } \\
\operatorname{vol}^{\mathrm{x}}\left(\mathrm{dm}^{3}\right)\end{array}$ \\
\hline \multicolumn{3}{|l|}{$\overline{\text { Ames }}$} \\
\hline oklahomensis & $98.1 \mathrm{a}^{\mathrm{w}}$ & $40.7 \mathrm{a}$ \\
\hline georgiensis & $98.7 \mathrm{a}$ & $38.8 \mathrm{a}$ \\
\hline maritima & $99.4 \mathrm{a}$ & $29.2 \mathrm{~b}$ \\
\hline \multicolumn{3}{|l|}{ Chanhassen } \\
\hline oklahomensis & $94.1 \mathrm{ab}$ & $43.3 \mathrm{a}$ \\
\hline georgiensis & $91.0 \mathrm{~b}$ & $29.5 \mathrm{ab}$ \\
\hline maritima & $97.3 \mathrm{a}$ & $27.6 \mathrm{~b}$ \\
\hline \multicolumn{3}{|l|}{ Lake George } \\
\hline oklahomensis & $69.4 \mathrm{c}$ & $3.8 \mathrm{~b}$ \\
\hline georgiensis & $80.2 \mathrm{~b}$ & $5.5 \mathrm{a}$ \\
\hline maritima & $91.5 \mathrm{a}$ & $5.3 \mathrm{a}$ \\
\hline \multicolumn{3}{|c|}{ Subspecies means across plots } \\
\hline oklahomensis & $87.2 \mathrm{c}$ & $29.3 \mathrm{a}$ \\
\hline georgiensis & $90.0 \mathrm{~b}$ & $24.6 \mathrm{ab}$ \\
\hline maritima & $96.1 \mathrm{a}$ & $20.7 \mathrm{~b}$ \\
\hline \multicolumn{3}{|c|}{ Plot means for A. maritima ${ }^{\mathrm{v}}$} \\
\hline Ames & $98.7 \mathrm{a}$ & $36.2 \mathrm{a}$ \\
\hline Chanhassen & $94.1 \mathrm{~b}$ & $33.4 \mathrm{a}$ \\
\hline Lake George & $80.4 \mathrm{c}$ & $4.9 \mathrm{~b}$ \\
\hline
\end{tabular}

${ }^{2} n=50$ for subspecies means within each plot; $n=150$ for subspecies means across plots.

yPercentage of the existing shoot that broke bud and grew.

${ }^{x}$ Canopy size calculated from three dimensional shoot measurements taken in mid-June 2001.

wMeans within each group of three followed by the same letter are not significantly different at $P \leq 0.05$ according to Fisher's least significant difference test.

${ }^{v}$ Plot means for the species A. maritima (main effect of plots, $\mathrm{n}=150$ ). 

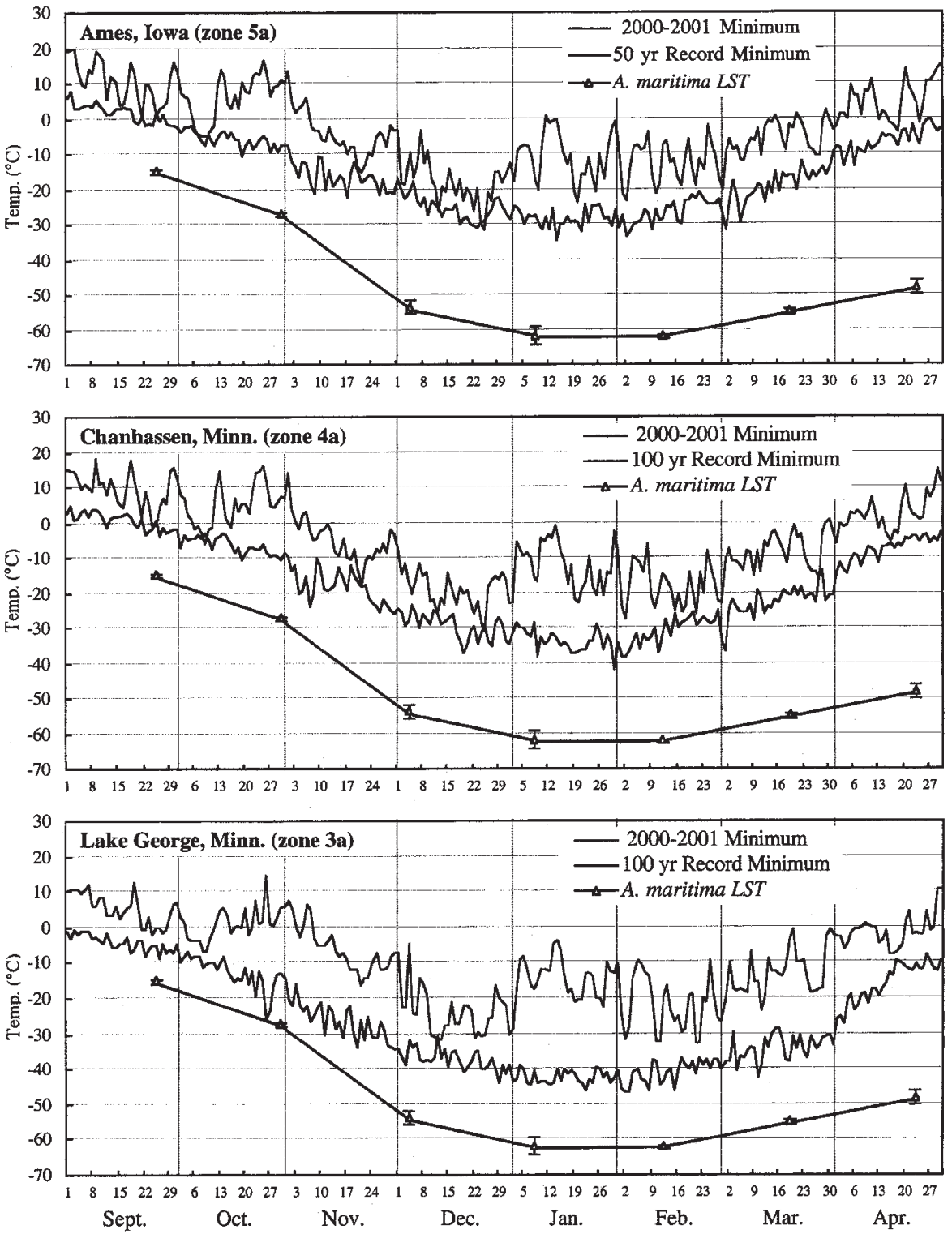

compared to the hardiness required for plants to exist in their native habitats (Table 1), we propose that the genotypic capacity for this strong cold hardiness was evolved in a much colder climate and was acquired before the divergence of the three subspecies. While some of the genotypes from A. maritima can withstand $-80^{\circ} \mathrm{C}$ in midwinter (Table 1, Fig. 3), we know that the other two members of subg. Clethropsis, A. nitida and A. nepalensis from southern Asia, cannot survive even $-31{ }^{\circ} \mathrm{C}$ (the coldest temperature recorded in Ames for Winter 2000-01), because all plants of A. nitida and A. nepalensis were killed at the Ames plot during Winter 2000-01 (Table 2, Fig. 4). The model of ancestral migration described above explains these data well. Alnus maritima appears to have acquired its extreme cold hardiness after its divergence from the other two members of Clethropsis and during its ancestral migrations through the area of the Bering Strait, but cold hardiness is lacking in A. nitida and $A$. nepalensis because their ancestral lines have never ventured beyond eastern and southern Asia (Furlow, 1979; Schrader, 2002; Schrader and Graves, 2002).

Alnus serrulata is the only species of Alnus with a distribution that overlaps that of $A$. maritima. Alnus serrulata is sympatric with $A$. maritima in Georgia and on the Delmarva Peninsula, and its continuous distribution begins as far north as Quebec, Canada (USDA zone 4a), and reaches into eastern Oklahoma, within 150 km of A. maritima (Furlow, 1979; Stibolt, 1981). Results from our cold hardiness plots reveal that genotypes of A. maritima and A. serrulata from the same localities have similar cold hardiness, with $A$. maritima being slightly more cold hardy. The similar pattern of cold hardiness in the two species supports the notion that $A$. maritima also once occurred over a large continuous distribution, which may have included areas with colder winter temperatures.

The phenology of dormancy and active growth reveals another area where the three subspecies of A. maritima have diverged somewhat. It has been demonstrated in several species that autumnal phenological events such as cessation of growth, leaf senescence, and leaf abscission are genetically controlled in response to shortening photoperiod, while spring phenological events (cold deacclimation, budbreak, and commencement of growth) appear to be less genetically controlled because they proceed in response to warming spring temperatures (Flint, 1972; Smithberg and Weiser, 1968). Our findings with the subspecies of A. maritima appear to follow this pattern. While there were only slight differences in the timing of budbreak among the three subspecies growing in our common garden (all 355 plants broke bud within a span of $12 \mathrm{~d}$ ), midseason growth rate, timing of the cessation of growth, and leaf abscission in the autumn showed greater variation (Fig. 5). Although genetic differences were evident for growth rate and autumnal phenology among the three subspecies (Fig. 5), no differences were resolved among subspecies for the timing of cold acclimation (Table 1), a phenomenon possibly explained by the observation of Flint (1972) that cold hardiness in established trees of Quercus rubra L. did not appear to be a factor important in natural selection.

The results of our cold-hardiness assessments demonstrate 
Shool Growth $\left(\mathrm{cm}^{3} / \mathrm{d}\right)$

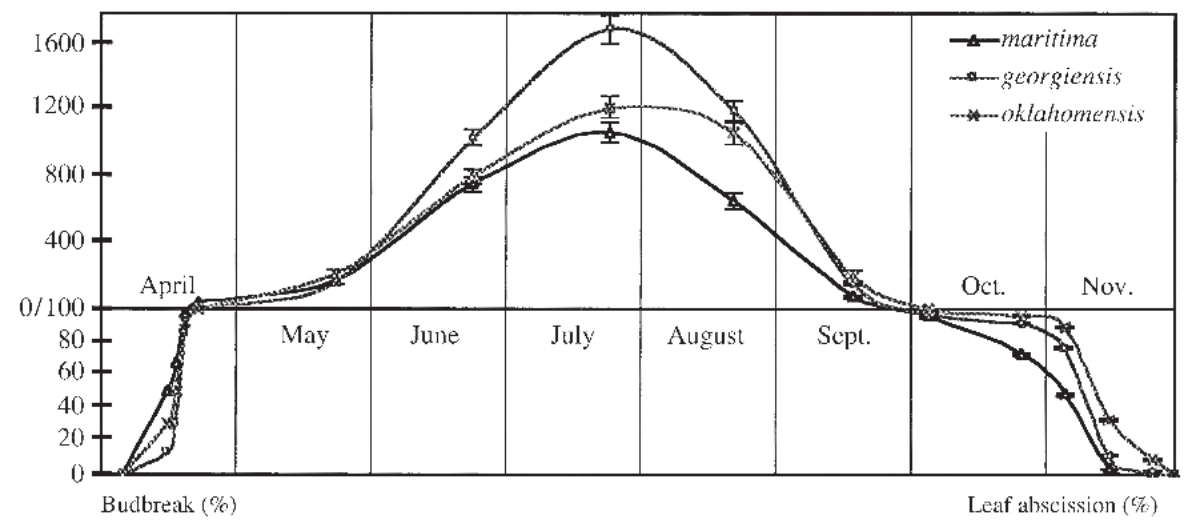

sibling groups showed mean tissue survival of 91.5\% after winter in Lake George (zone 3a) (Table 3), and two of these half-sibling groups showed $100 \%$ tissue survival at this location. It is likely that selections taken from subsp. maritima will include genotypes hardy to zone 3a. Even though genotypes from subsp. maritima appear to be slightly more cold hardy than those of the other two subspecies, rate of plant growth should also be one of the essential criteria for matching the proper genotype to local climates. Both subspp. oklahomensis and georgiensis grew faster than subsp. maritima in Ames (zone 5a) and Chanhassen (zone 4a) (Table 3). This greater capacity for growth may offset any added risk of tissue damage and may justify choosing one of these two subspecies over subsp. maritima for landscape applications in zones 5a and 4.

\section{Literature Cited}

Agriculture Research Service. 1990. USDA plant hardiness zone map. U.S. Dept. Agr. Misc. Publ. 1475.

Cochran, W.G. and G.M. Cox. 1992. Experimental designs. 2nd ed. Wiley, New York.

Flint, H.L. 1972. Cold hardiness of twigs of Quercus rubra L. as a function of geographic origin. Ecology 53:1163-1170.

Fuchigami, L.H., C.J. Weiser, and D.R. Evert. 1971. Induction of cold acclimation in Cornus stolonifera Michx. Plant Physiol. 47:98-103.

Furlow, J.J. 1979. The systematics of the American species of Alnus (Betulaceae). Rhodora 81:1-121,151-248.

Howell, G.S. and C.J. Weiser. 1970. The environmental control of cold acclimation in apple. Plant Physiol. 45:390-394.

Lindstrom, O.M. and K. Del Hierro. 1992. Leaf and stem cold hardiness estimates of six selections of chinese evergreen oak over two winter seasons. J. Environ. Hort. 10:11-13.

Lindstrom, O.M. and M.A. Dirr. 1991. Cold hardiness of six cultivars of chinese elm. HortScience 26:290-292.

McNamara, S. and H. Pellet. 1996. Cold hardiness of flowering crabapple cultivars. J. Environ. Hort. 14:111-114.

Pellet, H., M. Gearhart, and M. Dirr. 1981. Cold hardiness capability of woody ornamental plant taxa. J. Amer. Soc. Hort. Sci. 106:239-243.

SAS/STAT Software, version 6.12 of the SAS system for Power Macintosh. Copyright 1989-96. SAS Inst. Inc., Cary, N.C.

Schrader, J.A. 2002. Biosystematics and phenology of Alnus maritima (Betulaceae). PhD diss. Iowa State Univ., Ames.

Schrader, J.A. and W.R. Graves. 2000. Alnus maritima: A rare woody species from the New World. The New Plantsman 7:74-82.

Schrader, J.A. and W.R. Graves. 2002. Infraspecific systematics of Alnus maritima (Betulaceae) from three widely disjunct provenances. Castanea 67:380-401.

Smithberg, M.H. and C.J. Weiser. 1968. Patterns of variation among climatic races of red-osier dogwood. Ecology 49:495-504.

Stergios, B.G. and G.S Howell, Jr. 1973. Evaluation of viability tests for cold stressed plants. J. Amer. Soc. Hort. Sci. 98:325-330.

Stibolt, V.M. 1981. The distribution of Alnus maritima Muhl. ex Nutt. (Betulaceae). Castanea 46:195-200.

The Weather Channel. 1995-2002. Climatology index page. The Weather Channel Enterprises, Inc. 19 June 2002. <http://www.weather.com/ common/home/climatology.html>.

Vezina, L.P., J.M. Ferullo, G. Laliberte, S. Laberge, and C. Willemot. 1997. Chilling and freezing, p. 61-100. In: M.N.V. Prasad (ed.). Plant ecophysiology. Wiley, New York. 